JURNAL ILMIAH ELEKTRONIKA DAN KOMPUTER, Vol.14, No.2, Desember 2021, pp. 332 - 338

p-ISSN : 1907-0012 (print)

e-ISSN : 2714-5417 (online)

http://journal.stekom.ac.id/index.php/elkom

- page 332

\title{
PERANCANGAN SISTEM INFORMASI PENYEWAAN LAPANGAN FUTSAL BERBASIS WEB MOBILE
}

\author{
Rudi Khairizal ${ }^{1}$, Teguh Khristianto ${ }^{2}$, Isworo Nugroho ${ }^{3}$ \\ ${ }^{1}$ Sistem Informasi UNISBANK Semarang \\ J1. Trilombajuang No. 1, Semarang, rudikhairizal15@gmail.com \\ ${ }^{2}$ Sistem Informasi, UNISBANK Semarang \\ Jl. Trilombajuang No. 1, Semarang, teguhkhris@edu.unisbank.ac.id \\ ${ }^{3}$ Sistem Informasi, UNISBANK Semarang \\ Jl. Trilombajuang No. 1, Semarang, wwk6259@gmail.com
}

Article history:

Received 24 November 2021

Received in revised form 26 November 2021

Accepted 26 Novenber 2021

Available online 1 Desember 2021

\begin{abstract}
A web-based futsal field reservation system was developed to help facilitate the process of booking or leasing a futsal field. The system uses PHP and HTML programming languages by using MySQL as data storage. The purpose of designing this system is to make it easier for users to rent futsal fields. With the futsal field reservation system is expected to facilitate in data processing, scheduling and registration of members or customers. In the end, this system is expected to help the company's performance, and can also facilitate customers in the ordering process.
\end{abstract}

Keywords: Reservations, futsal, booking, web.

\begin{abstract}
Abstrak
Sistem reservasi lapangan futsal berbasis web dikembangkan untuk membantu memfasilitasi proses pemesanan atau penyewaan lapangan futsal. Sistem ini menggunakan bahasa pemrograman PHP dan HTML dengan menggunakan MySQL sebagai penyimpanan data. Tujuan dari mendesain sistem ini untuk memudahkan pengguna melakukan penyewaan lapangan futsal. Dengan adanya sistem reservasi lapangan futsal diharapkan dapat mempermudah dalam pengolahan data, penjadwalan dan pendaftaran anggota atau pelanggan. Pada akhirnya sistem ini diharapkan dapat membantu kinerja perusahaan, dan juga dapat memfasilitasi pelanggan dalam melakukan proses pemesanan.
\end{abstract}

Keywords: Reservations, futsal, booking, web.

\section{Pendahuluan}

Sistem teknologi berkembang sangat cepat hari ini, sehingga sistem informasi layanan juga harus ditingkatkan. Penyewaan futsal adalah entitas bisnis yang bergerak di bidang olahraga. Secara umum, proses bisnis di tempat penyewaan lapangan futsal masih mengharuskan pelanggan untuk datang untuk menyewa dan mengatur jadwal sewa yang diinginkan. Sehingga pelanggan tidak mengetahui harga dan jadwal yang masih kosong secara langsung [1]. 
Berdasarkan uraian di atas, dibutuhkan sistem informasi sewa lapangan futsal online untuk membantu perusahaan dalam memberikan layanan kepada pelanggan seperti ketersediaan jadwal lapangan yang kosong, kemudian memudahkan pelanggan untuk mendapatkan informasi seperti harga sewa lapangan, dan dapat melakukan pemesanan lapangan futsal online.

Penulis mencoba mengembangkan aplikasi web yang menyediakan layanan dan sistem informasi pemesanan untuk mengelola bisnis penyewaan lapangan futsal. Dengan aplikasi ini, pengusaha (pemilik) lapangan futsal dapat mempromosikan lapangan futsalnya dan mengelola jadwal pemesanan.

Sistem informasi penyewaan futsal ini menghasilkan program pemesanan lapangan yang dapat dilakukan melalui web. Sistem informasi yang dibangun diharapkan dapat memenuhi kebutuhan pelanggan yang ingin memesan lapangan futsal. Dalam tulisan ini, penulis akan membahas cara merancang dan membangun Sistem Informasi yang lebih mudah dan mudah digunakan.

\section{Tinjauan Pustaka}

Penelitian yang dilakukan oleh [2] berjudul Sistem Informasi Penyewaan Mobil Berbasis Web di GTS Mobil Bandung. Metodologi ini menggunakan Waterfall yang terdiri dari tahapan Analisis Kebutuhan, Desain Sistem, Pengkodean, Pengujian Program, Pemeliharaan. Sedangkan bahasa pemrograman yang digunakan adalah bahasa pemrograman PHP dan database menggunakan database MySQL. Berdasarkan hasil penelitian, aplikasi penyewaan mobil ini dapat mengakomodasi kebutuhan pada kegiatan transaksi sewa, reservasi, pembayaran sehingga perusahaan dapat memperoleh lebih akurat informasi dari setiap kegiatan yang dilakukan [3]

Penelitian yang dilakukan oleh [4] berjudul Sistem Informasi Sewa Bus Online Berbasis Web di Dinas Perhubungan Kabupaten Barito Kuala. Tujuan dari penelitian ini adalah untuk membangun sistem informasi sewa bus. sehingga pemesanan dan penyewa bus dapat melakukan transaksi secara online dan memudahkan pelanggan untuk mendapatkan informasi tentang jadwal keberangkatan, ketersediaan bus dan informasi tentang layanan yang diberikan tanpa harus mengunjungi perusahaan.

Penelitian yang dilakukan oleh [5] berjudul Implementasi dan Pengujian Sewa Kendaraan Bermotor Sistem Informasi Layanan Menggunakan Standar ISO 9126 Studi Kasus: PT. XYZ. Penelitian ini bertujuan untuk membuat model sistem informasi layanan penyewaan kendaraan bermotor yang mampu membantu memberikan pelayanan yang optimal. Dalam penelitian ini, Penulis menggunakan Analisis dan Desain Berorientasi Objek Metodologi (OOAD) untuk pengembangan sistem yang diusulkan, bahasa pemrograman menggunakan Microsoft Visual Net 2008, perangkat lunak database menggunakan MySQL.

\section{Sistem Informasi}

Dalam arti luas, sistem informasi dapat dipahami suatu subsistem yang saling berhubungan, bersama-sama dan membentuk satu unit, berinteraksi dan bekerja sama satu sama lain dengan cara tertentu untuk melakukan pemrosesan data, dan menerima input (input) dalam bentuk data, kemudian memprosesnya (mengolahan), dan menghasilkan output dalam bentuk informasi sebagai dasar pengambilan keputusan yang berguna dan memiliki nilai nyata yang dapat dirasakan sebagai hasilnya baik pada saat itu waktu dan di masa depan. Sistem informasi mendukung kegiatan operasional manajerial, dan membantu menentukan strategi untuk mencapai tujuan organisasi [6]

PERANCANGAN SISTEM INFORMASI PENYEWAAN LAPANGAN FUTSAL BERBASIS WEB MOBILE (Rudi Khairizal) 


\section{Pengertian Sewa Menyewa}

Menurut [7], sewa-menyewa adalah pihak yang satu menyanggupi akan menyerahkan suatu benda untuk dipakai selama suatu jangka waktu tertentu sedangkan pihak yang lainnya menyanggupi akan membayar harga yang telah ditetapkan untuk pemakaian itu pada waktuwaktu yang ditentukan.

\section{MySQL}

MySQL (My Structured Query Language) merupakan database yang paling favorit saat ini. Program ini berjalan sebagai server yang menyediakan multi-user, dan dapat mengakses sejumlah database. MySQLAB merupakan database yang tidak berbayar, di bawah GNU General Public Lisensi (GPL), tetapi ada juga MySQL berbayar [8].

\section{Metodologi Penelitian}

Metode penelitian menggunakan model Prototype seperti pada gambar 1 berikut ini :

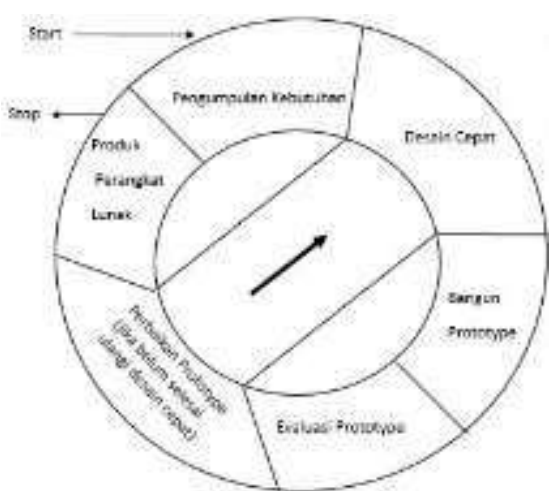

Gambar 1. Metode penelitian dengan model Prototype

\section{Hasil dan Pembahasan}

Berikut berbagai tahapan yang dilakukan pada model Prototype dengan hasil dan pembahasannya :

\section{1) Pengumpulan Kebutuhan}

Pengembang (developer) dan pemakai (user) bertemu untuk mengidentifikasi secara rinci kebutuhan apa saja yang akan digunakan sebagai spesifikasi sistem. Tujuan pada tahap ini yaitu memahami sistem yang ada sehingga diharapkan dapat menghasilkan suatu alternatif pemecahan masalah sesuai kebutuhan pemakai. Hasil identifikasi yang dihasilkan yaitu admin dapat menginput, mencetak sertifikat sesuai alat yang diajukan, marketing dapat melaporkan data customers. Sementara itu untuk kebutuhan perangkat lunak yang digunakan yaitu untuk OS Windows 10 dengan bahasa pemrograman PHP dan HTML serta editor Adobe Dreamweaver CS5 sedangkan berkaitan dengan data base menggunakan MySql dan XAMPP ControlPanel v3.2.2.

\section{2) Desain Cepat}

Dalam tahap ini digunakan pemodelan UML yang meliputi use case diagram dan class diagram serta perancangan desain tampilan menu yang akan di buat

JURNAL ILMIAH ELEKTRONIKA DAN KOMPUTER Vol. 14, No. 2, Desember 2021: $332-338$ 


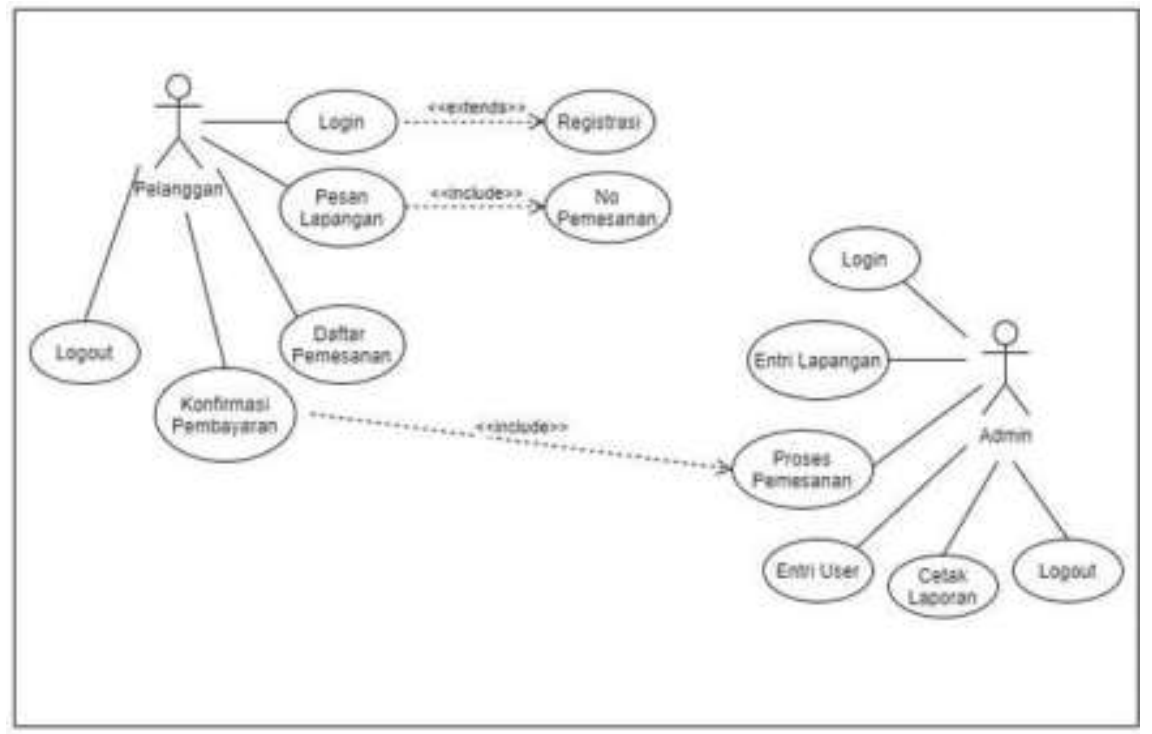

Gambar 2. Use case diagram

Pelanggan melakukan login atau melakukan registrasi kemudian memesan lapangan futsal dengan memilih lapangan futsal yang akan dipesan kemudian mendapatkan nomor pemesanan. Pelanggan juga dapat melihat daftar pemesanan lapangan futsal pada menu daftar pemesanan. Admin melakukan login kemudian melakukan entri lapangan futsal, pemesanan, user, mencetak laporan pelanggan, laporan konfirmasi dan laporan pemesanan dan logout untuk keluar dari sistem.

Pemodelan selanjutnya yaitu dengan membuat model class diagram yang nantinya akan dijabarkan dalam bentuk tabel berupa field, tipe dan ukuran pada perancangan database. Untuk lebih jelasnya dapat dilihat pada gambar dibawah ini.

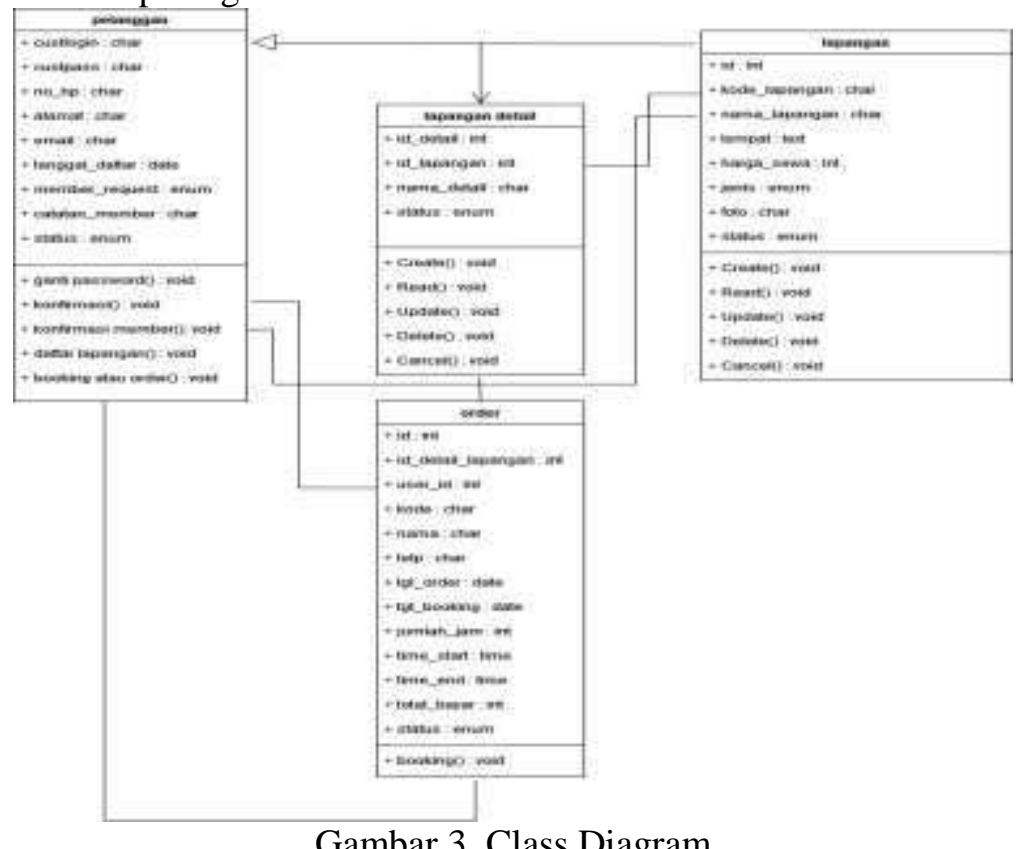

Gambar 3. Class Diagram 
Class pelanggan dengan primary key custlogin berelasi dengan class lapangan dengan id_lapangan berasosiasi dengan class order. Class pelanggan dengan konfirmasi berelasi dengan user_id berasosiasi dengan class order. Class pelanggan dengan konfirmasi_member berasosiasi dengan class lapangan.

\section{3) Bangun Prototype}

Pembuatan Prototype dilakukan dengan menggunakan aplikasi PHP dan HTML dengan hasil sebagai berikut :

Halaman Login. Merupakan halaman yang digunakan admin dan pelanggan untuk masuk kedalam sistem dengan menginputkan username dan password.

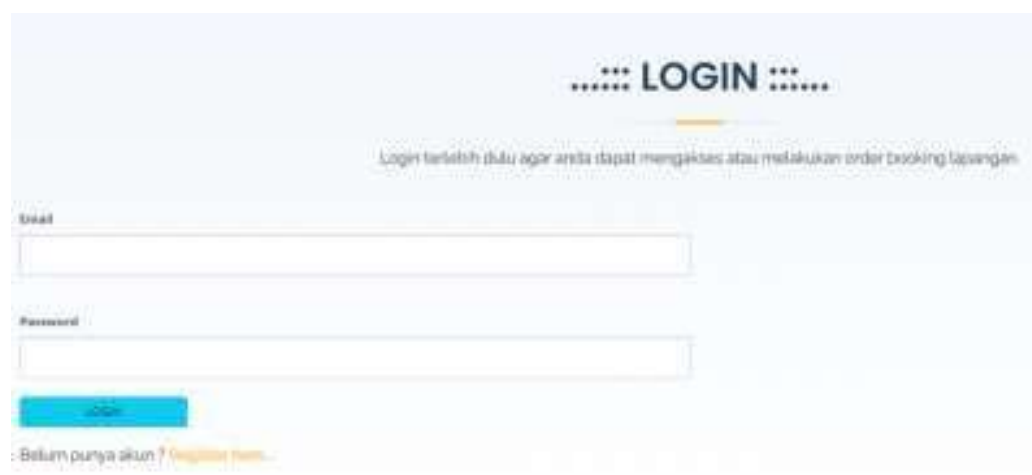

Gambar 4. Tampilan halaman login

Halaman dashboard Admin. Halaman ini sebagai tampilan pertama sesudah login sebagai Admin yang terdiri dari tombol tekan (push button) customers, alat, cetak, laporan, dan setting.

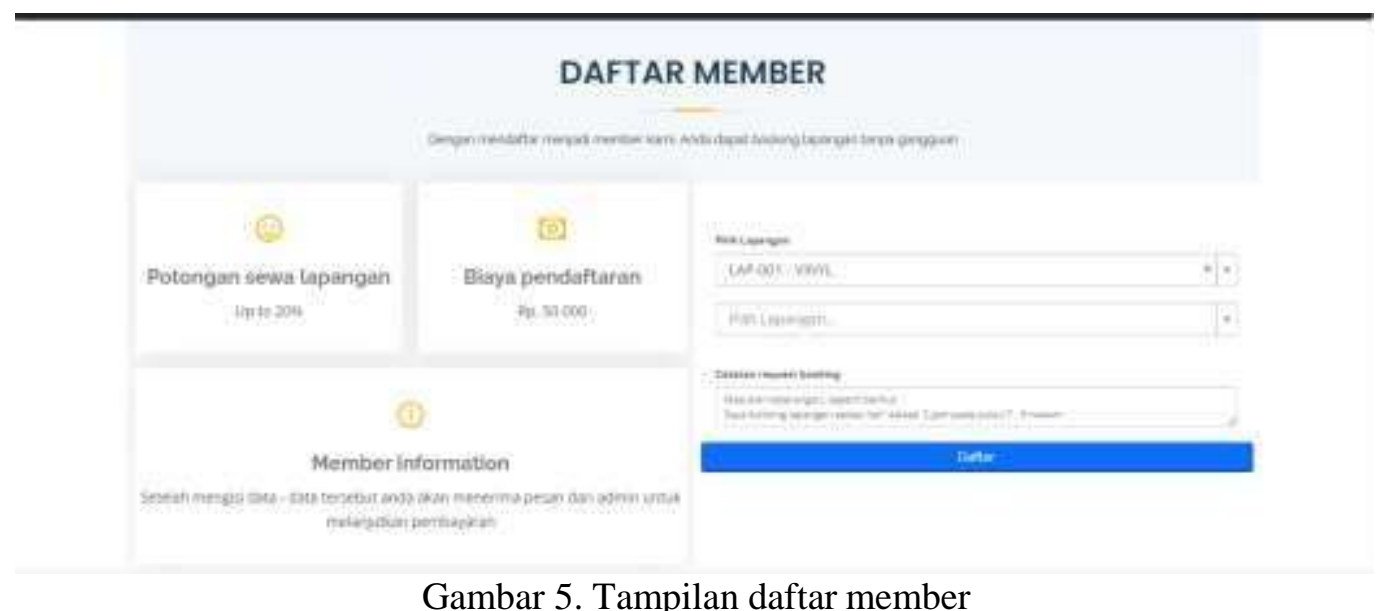

Daftar member seperti gambar 5. digunakan untuk mendaftar sebagai member pelanggan. Pilih lapangan member bisa memilih lapangan sesuai kebutuhan, dan member harus membayar biaya pendaftaran sebagai member. 


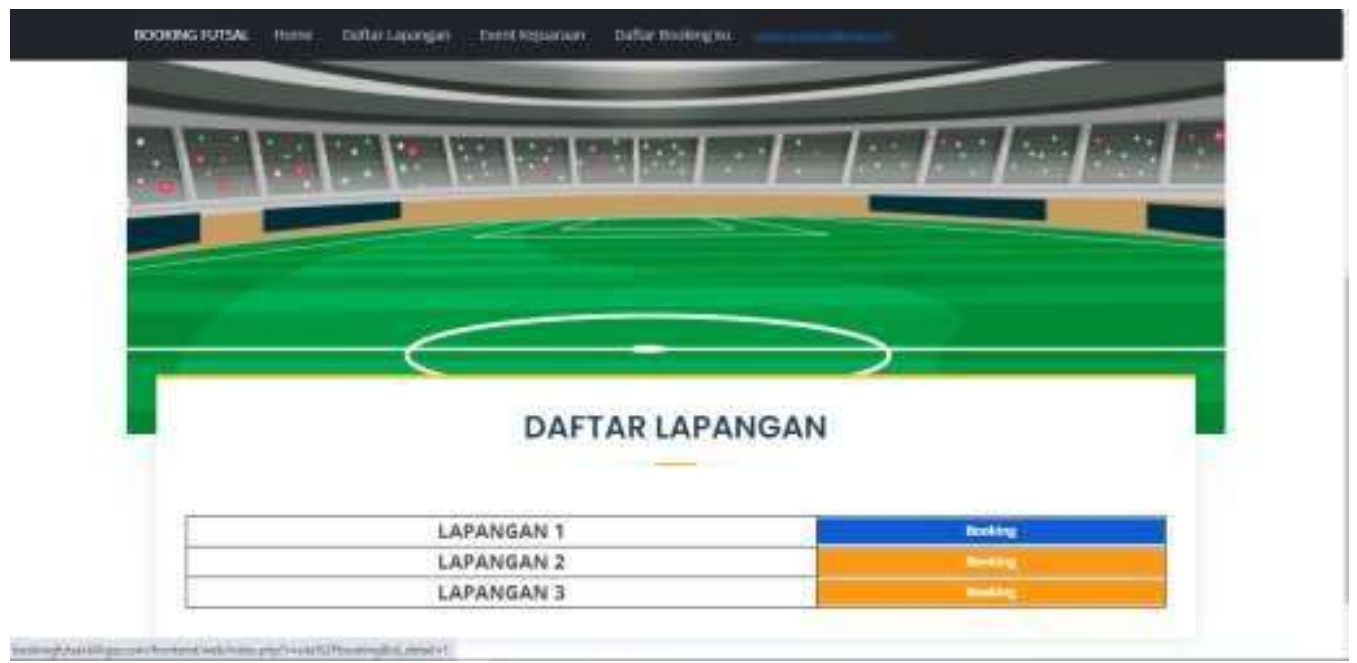

Gambar 5. Booking

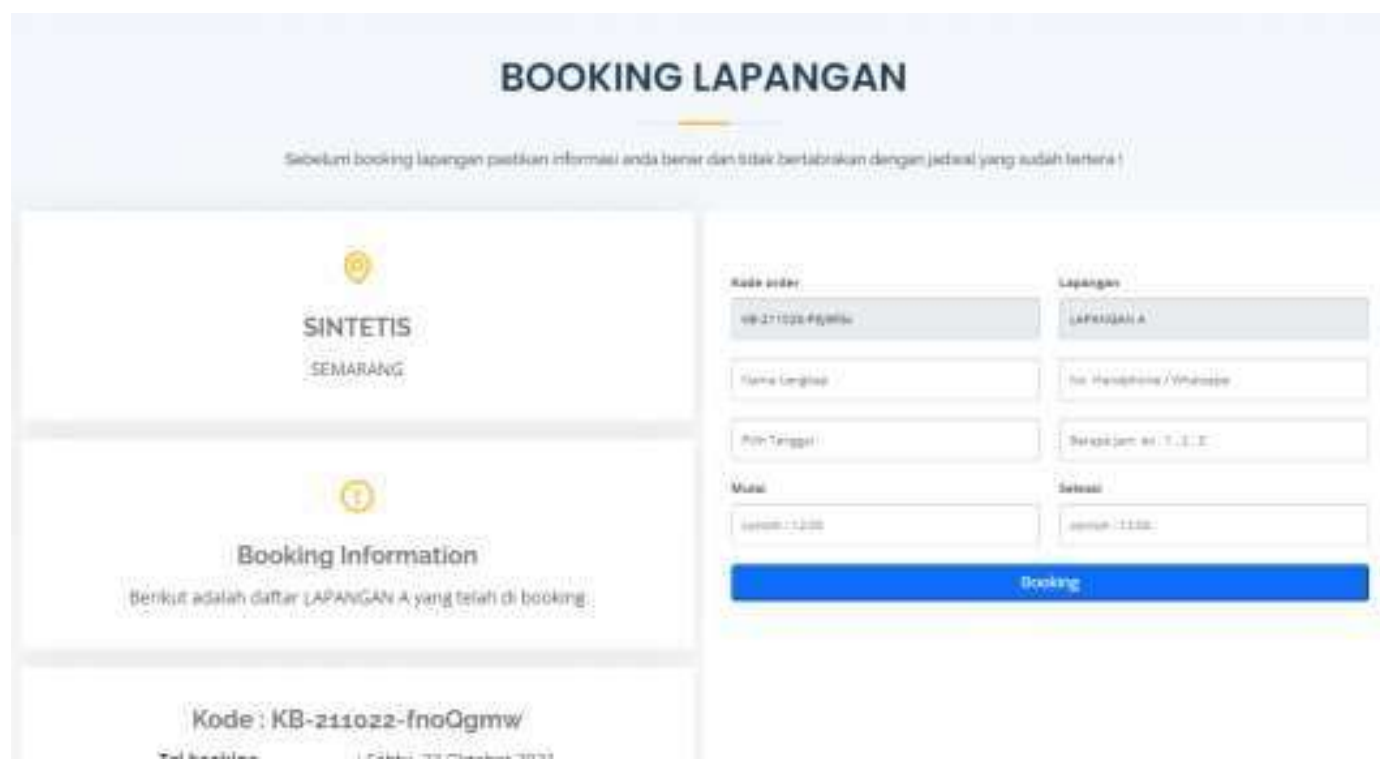

Gambar 6. Data Booking

Booking seperti gambar 5. digunakan pelanggan untuk melakukan pemesanan lapangan futsal secara online. Pelanggan dapat memilih lapangan futsal yang ingin dipesan lalu dapat mengklik "Booking" untuk mengisi data pemesanan. Pelanggan dapat mengisi data booking (gambar 6) Nama Lengkap yaitu nama pelanggan, No. Handphone pelanggan, Tanggal Booking yaitu tanggal pemesanan lapangan futsal, Jam Mulai yaitu jam mulai bermain, Lama yaitu lama pemesanan, Jam Selesai yaitu jam selesai bermain.

\section{4) Evaluasi Prototype}

Untuk melihat apakah sistem informasi ini sudah berjalan dengan baik maka perlu dilakukan pengujian terhadap fungsionalitas dari fitur-fitur yang disediakan. Apabila ditemukan adanya kekurangan / error maka akan kembali ke tahapan Modelling dan Designing. 


\section{5) Produk Perangkat Lunak}

Hasil akhir prototype didasarkan pada perbaikan sistem informasi berdasarkan pada error dari hasil pengujian yang dilakukan sebelumnya seperti contoh error pada fitur Search. Dalam hal ini apabila pengujian yang dilakukan sudah berjalan dengan baik dan tidak terdapat kesalahan / error maka sistem sudah dapat dioperasikan dengan baik.

\section{Kesimpulan}

Berdasarkan hasil dan diskusi sebelumnya dijelaskan serta hasil dan analisis desain dan pembangunan sewa lapangan futsal berbasis web sistem informasi, dapat diringkas sebagai berikut:

Sistem informasi ini dapat membantu admin dalam memproses jadwal lapangan futsal. Informasi ini sistem dapat memberikan informasi kepada pelanggan tentang Jadwal lapangan futsal tanpa harus datang secara langsung. Sistem informasi ini dapat membantu anggota untuk memesan futsal. pengadilan online.

Berdasarkan hasil pembuatan informasi ini sistem, penulis menyarankan hal-hal berikut: Untuk masa depan, Sistem informasi ini masih dapat dikembangkan sejalan dengan pengembangan spesifikasi persyaratan pengguna. Ke memelihara data atau sistem informasi ini, lebih baik mencadangkan data untuk menghindari kerusakan pada sistem.

\section{Daftar Pustaka}

[1] Rahma, N. A., Wijaya, R.D.. Aplikasi Penyewaan Lapangan Futsal Berbasis Web Dan Sms Gateway, eProceedings of Applied Science, 2015; 1 (1), 663.

[2] Ginanjar, Gilang (2014) Sistem Informasi Penyewaan Mobil Berbasis Web di GTS Mobil Bandung. Diploma thesis, Universitas Komputer Indonesia.2014. https://repository.unikom.ac.id/id/eprint/29351

[3] Subhan M. Analisa Desain Sistem. Lentera Ilmu Cendekia: Jakarta. 2012.

[4] Fitria and Yulia Nisa. Sistem Informasi Penyewaan Bus Online Berbasis Web Pada Dinas Perhubungan Kabupaten Barito Kuala, PHASTI, 2017; 3 (2),19-24.

[5] Hamdani, A. U. Implementasi Dan Pengujian Sistem Informasi Jasa Penyewaan Kendaraan Bermotor Menggunakan Standar ISO 9126 Studi Kasus : PT. XYZ, SITEKIN, 2016; 13 (2), 218-228.

[6] Sutanta, Edhy, Basis Data dalam Tinjauan Konseptual. Yogyakarta: Publisher Andi. 2011.

[7] Subekti, Aneka Perjanjian, Alumni, Bandung, 1975,

[8] Prasetyo, Y. Yudhanto and Helmi Adi. Panduan Mudah Belajar Framework Laravel. Jakarta: PT Elex Media Komputindo. 2019. 